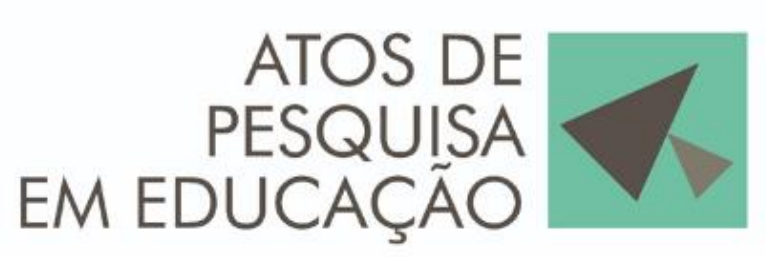

ISSN: 1809-0354

\title{
TEMPO INTEGRAL E VALORIZAÇÃO DOCENTE EM PLANOS DE EDUCAÇÃO E DE CARREIRA NO ESTADO DO RIO DE JANEIRO
}

\author{
FULL-TIME EDUCATION AND TEACHER VALORIZATION IN PLANS OF \\ EDUCATION AND CAREER IN THE STATE OF RIO DE JANEIRO
}

\section{EDUCACION EN TIEMPO COMPLETO Y VALORACIÓN DE PROFESORES EN PLANES DE EDUCACIÓN Y CARRERA EN EL ESTADO DE RÍO DE JANEIRO}

\author{
COELHO, Lígia Martha C. C. \\ ligiamartha25@outlook.com \\ Unirio - Universidade Federal do Estado do Rio de Janeiro \\ https://orcid.org/0000-0002-3892-3308 \\ HORA, Dayse Martins \\ daysehora@yahoo.com.br \\ UCP - Universidade Católica de Petrópolis \\ https://orcid.org/0000-0002-1203-270X \\ GUILARDUCCI, Raphael Mota \\ rhmguila@gmail.com \\ UFRJ - Universidade Federal do Rio de Janeiro \\ https://orcid.org/0000-0002-8344-1105
}

\begin{abstract}
RESUMO: $O$ artigo analisa a valorização docente em políticas de tempo integral, no estado do Rio de Janeiro. A pesquisa bibliográfica e a análise da legislação apresentam a valorização e o tempo integral nas metas e estratégias que versam sobre essas temáticas, em Planos Municipais de Educação e Planos de Carreira e Remuneração dos Profissionais do Magistério, nos municípios de Duque de Caxias, Miracema e Resende. Seus resultados evidenciam a valorização docente nos documentos municipais, contemplada por meio de ações que visam melhorias das condições de trabalho. A jornada de tempo integral também é abordada, mas sem um detalhamento dos caminhos para sua efetivação. Não houve, na pesquisa documental, uma aproximação entre valorização do trabalho docente e educação em tempo integral que se materializasse em propostas efetivas.
\end{abstract}

Palavras-chave: Educação em Tempo Integral. Valorização do trabalho docente. Planos Municipais de Educação. Planos de Carreira e Remuneração do Magistério.

ABSTRACT: The article analyzes teacher valorization processes in full-time education policies in the state of Rio de Janeiro. The bibliographic research and the analysis of the legislation present the valorization and the full-time in the goals and strategies that deal with these themes, indicated in the Municipal Education Plans and Teaching career Plans of Duque de Caxias, Miracema and Resende. The results confirm the presence of teacher valorization in the municipal documents, contemplated through 


\section{ATOS DE

actions that aimed to improve working conditions. Full-time education is also covered, but without detailing the paths for its effectiveness. In the municipal documents there was no approximation between valorization of teaching work and full-time education that demonstrated effective proposals.

Keywords: Full-Time Education. Valorization of teaching work. Municipal Education Plans. Teaching Career Plans.

RESUMEN: El artículo analiza la valorización de los profesores en las políticas de tiempo completo, en el estado de Río de Janeiro. La investigación bibliográfica y el análisis de la legislación presentan la valorización y el tiempo completo en las metas y estrategia acerca de estos temas, en los Planes Municipales de Educación y Planes de Carrera y Remuneración para los Profesionales del Magisterio, en los municipios de Duque de Caxias, Miracema y Resende. Sus resultados muestran la valorización de los docentes, en los documentos municipales, presentados a través de acciones que intentan mejorías de condiciones de trabajo. El día laboral de tiempo completo es planteado, pero sin detallar los caminos para su efectividad. En la pesquisa documental, no hubo una aproximación entre valorización del trabajo docente y la educación a tiempo completo que se materializaran en propuestas efectivas.

Palabras clave: Educación de Tiempo Completo. Trabajo docente. Valorización del trabajo docente. Planes Municipales de Educación. Planes de Carrera Docente.

\section{INTRODUÇÃO}

A história do trabalho relaciona-se diretamente à história da sociedade: é o trabalho que materializa a existência humana, possibilitando condições de sobrevivência - ou não. No Brasil assistimos a uma discussão intensa, que impacta tanto o trabalho quanto o mundo do trabalho, construindo um cenário de jogos de poder, presente também, nas políticas educacionais do país.

Em meio aos impactos que reformas como a trabalhista e a previdenciária trazem para esse campo de discussão, interessa-nos especificamente o trabalho docente, cujas características são muito próprias. Essas têm nas legislações educacionais vigentes - Lei de Diretrizes e Bases da Educação Nacional (LDBEN Lei no 9.394/96); Plano Nacional de Educação (PNE - Lei no 13.005/2014) desdobramentos em atos normativos, como Planos Estaduais (PEE) e Planos Municipais de Educação (PME) - aporte legislativo para sua efetivação.

O interesse no trabalho docente e especificamente, na discussão sobre sua valorização está na base da investigação que empreendemos. Com objetivo de apresentar os PMEs do estado do Rio de Janeiro, levamos em consideração uma 


\section{ATOS DE

possível relação das Metas 15 a 18 - presentes no PNE/2014 - com a construção da educação em tempo integral (Meta 6 desse mesmo Plano) nas redes de ensino municipais².

A partir da legislação educacional vigente, pretendemos discutir e analisar a valorização dos professores como processo fundamental à constituição do trabalho docente, especificamente quando em exercício nas redes e sistemas de ensino que preveem a educação em tempo integral. Por meio de pesquisa bibliográfica são apresentados conceitos de mundo do trabalho e trabalho docente (ANTUNES, 2005; FIGARO, 2008), esse último acrescido de problematização sobre a valorização (LEHER, 2010), para responder a questões como: o que se entende por valorização do trabalho docente na legislação federal e nos planos de municípios que compõem o estado do Rio de Janeiro? Estarão as estratégias que valorizam esse trabalho docente afinadas com qual concepção de ampliação da jornada escolar?

O artigo é produto de uma pesquisa mais ampla, na qual durante a primeira etapa, realizamos aproximação aos ordenamentos legais municipais que evidenciam metas e diretrizes relacionadas à valorização docente, bem como à educação em tempo integral. Nesse estudo, apresentamos um recorte dos municípios escolhidos, a partir de sua proporcionalidade em relação ao universo dos noventa e dois que compõem o estado do Rio de Janeiro. ${ }^{3}$ Esse recorte baseou-se em três critérios, utilizados nesta ordem: (i) municípios, por região político-administrativa, que possuem o maior número de estudantes matriculados no Ensino Fundamental; (ii) municípios, por região político-administrativa, que possuem projeto/política pública de educação em tempo integral e (iii) municípios, por região político-administrativa, que tenham instituído Planos de Carreira e Remuneração dos Profissionais do Magistério da Educação Básica Pública (PCR).

\footnotetext{
1 Exatamente as que se referem à formação e valorização dos profissionais da educação: 15 Formação de professores; 16 - Formação continuada e pós-graduação de professores; 17 Valorização do professor; 18 - Plano de carreira docente.

2 Estamos nos referindo a pesquisa interinstitucional, aprovada pelo Departamento de Pesquisa (DPq) da Universidade Federal do Estado do Rio de Janeiro (UNIRIO) e pela Universidade Católica de Petrópolis (UCP), no segundo semestre de 2017, para realização em um período de quatro (4) anos.

${ }^{3}$ O Estado do Rio de Janeiro está dividido em oito Regiões de Governo, segundo a Lei n. 1.227/87, que aprovou o Plano de Desenvolvimento Econômico e Social 1988/1991. São elas: Metropolitana, Noroeste Fluminense, Norte Fluminense, Baixadas Litorâneas, Serrana, Centro-Sul Fluminense, Médio Paraíba e Costa Verde.
} 


\section{ATOS DE \\ PESQUISA \\ EM EDUCAÇÃO}

ISSN: 1809-0354

4

O recorte inicial da investigação - quinze municípios - foi trabalhado em cinco grupos de três e, para este texto, restringimo-nos ao primeiro grupo, formado por Duque de Caxias (Região Metropolitana - Baixada Fluminense); Miracema (Região Noroeste Fluminense - interior do estado) e Resende (Região do Médio Paraíba cidade industrial). $\mathrm{O}$ trabalho está organizado em três partes. A primeira busca a discussão teórica dos conceitos que norteiam nossa análise, a saber, trabalho docente e valorização dos profissionais do magistério das redes públicas de educação básica. A segunda parte coteja dados dos PME com os PCR dos Profissionais do Magistério da Educação Básica Pública dos municípios selecionados para o presente recorte. A terceira e última parte direciona a reflexão para as propostas de educação em tempo integral, colocando em cena a valorização do professor das redes públicas de educação básica do estado do Rio de Janeiro para estas mesmas propostas.

Partimos, inicialmente, de duas questões norteadoras: $O$ que entendemos por trabalho docente e valorização do magistério? Como essas categorias de análise se evidenciam e articulam em documentos federais e/ou municipais que tratam da educação e, mais especificamente, da educação em tempo integral?

\section{DISCUTINDO TRABALHO DOCENTE E VALORIZAÇÃO DO MAGISTÉRIO}

Antes de iniciarmos a discussão proposta no título desta parte, cabe a apresentação de uma questão político-conceitual que atravessa nosso estudo, cuja definição foi tomada anteriormente às análises da investigação mais ampla a que já nos referimos. Trata-se dos documentos legais que utilizamos - LDBEN/1996; PNE/2014; Planos Municipais de Educação e Planos de Carreira - e o uso que fazem de expressões/conceitos diferentes, ao se referirem aos professores ou gestores educacionais.

A LDBEN/1996 utiliza o termo profissionais da educação escolar básica quando define a formação para o exercício de suas funções, quer sejam elas em regência de sala de aula ou na gestão escolar. O PNE/2014 se alinha a esse mesmo campo semântico - com o uso da expressão formação dos profissionais da educação - ao descrever as metas 15 e 16, que dizem respeito à formação. Nas metas 17 e 18 - da 


\section{ATOS DE

ISSN: 1809-0354

valorização -, o $\mathrm{PNE} / 2014$ emprega o termo profissionais do magistério. Logo, mantém expressões não idênticas, mas que guardam similaridade.

No caso dos PCR, nos municípios de Duque de Caxias, Miracema e Resende buscamos suporte na Resolução CNE/CEB no2/2009, que fixa as diretrizes nacionais para formulação dos referidos Planos. Nesse documento legal, a referência é feita aos profissionais do magistério da educação básica pública. É preciso evidenciar que, ao elaborarem seus PCR, nesses municípios selecionados, fica a questão de que alguns deles ainda possuem escolas de ensino médio sob sua competência federativa, sendo possível a alusão a toda a educação básica. Entretanto, eles utilizam como título aos seus planos, magistério público do município ou profissionais da educação, porque estão congregando em um único PCR, o Magistério e os profissionais de Serviços de Apoio Escolar nas Unidades Escolares, em órgãos centrais da Secretaria de Educação.

É preciso salientar que, nas diretrizes da Resolução CNE/CEB №2/20094 , há uma clara distinção entre os profissionais do magistério (docentes e gestores escolares) e os demais profissionais da educação (profissionais de apoio tais como merendeiras, cozinheiras, porteiros, zeladores, inspetores de alunos etc.), expressa em seu $\S 1^{\circ}$ do Art. $2^{\circ}$ :

$\S 1^{0}$ São considerados profissionais do magistério aqueles que desempenham as atividades de docência ou as de suporte pedagógico à docência, isto é, direção ou administração, planejamento, inspeção, supervisão, orientação e coordenação educacionais, exercidas no âmbito das unidades escolares de Educação Básica, em suas diversas etapas e modalidades (Educação Infantil, Ensino Fundamental, Ensino Médio, Educação de Jovens e Adultos, Educação Especial, Educação Profissional, Educação Indígena), com a formação mínima determinada pela legislação federal de Diretrizes e Bases da Educação Nacional.

Seguindo a Resolução CNE/CEB no 2/2009, o Conselho Nacional de Educação previu a possibilidade de planos distintos ou únicos para contemplar os diversos profissionais da educação, remetendo assim a docentes e não docentes:

\footnotetext{
${ }^{4}$ Esta resolução fixa as Diretrizes Nacionais para os Planos de Carreira e Remuneração dos Profissionais do Magistério da Educação Básica Pública. O Ministério da Educação, através de sua Secretaria de Articulação com os Sistemas de Ensino, publicou em 2016 um documento orientador para elaboração dos planos de carreira e remuneração no âmbito nacional (BRASIL, 2016). Entretanto, esse documento mantém como referência a Resolução CNE/CEB № 2/2009.
} 


\section{ATOS DE \\ PESQUISA EM EDUCAÇÃO}

ISSN: 1809-0354

6

$\S 2^{0}$ Os entes federados que julgarem indispensável a extensão dos dispositivos da presente Resolução aos demais profissionais da educação poderão aplicá-los em planos de carreira unificados ou próprios, sem nenhum prejuízo aos profissionais do magistério.

Nessa perspectiva, e levando em consideração o fato de que nosso interesse de pesquisa se centra, exatamente, nos sujeitos em atuação pedagógica no espaço escolar (os professores) como impulsionadores de conhecimentos e saberes sócio historicamente constituídos, neste artigo estamos trabalhando com o conceito de magistério da educação básica, o que justifica, também, o emprego de formação para o magistério e valorização do professor ou valorização do magistério. Crendo que fizemos esclarecimentos conceituais necessários, assumindo nossa opção neste estudo, passemos à discussão do trabalho docente e da valorização, entendendo as funções do magistério como aquelas exercidas na escola, em sala de aula ou em atividade de coordenação pedagógica e direção.

A temática do trabalho docente vem se colocando com maior expressão no cenário das pesquisas educacionais, frequentemente associada ao mundo do trabalho. Considerado como conceito polissêmico (ANTUNES, 2005), para Figaro (2008, p.92) o mundo do trabalho compreende "[...] um conjunto de fatores que engloba e coloca em relação a atividade humana de trabalho [...] um micro-organismo da sociedade, que embora tenha especificidade, é capaz de revelá-la".

A importância dada ao trabalho docente na Educação parece ser ainda tangencial quanto à amplitude que se estabelece quando pensamos no mundo do trabalho. Ela se apresenta na relação com a avaliação em larga escala; na dinâmica de reestruturação e regulação dos processos escolares, levantando questões de autonomia deste e sobre este trabalho; na formação do professor; nas histórias de vida e sua relação com o trabalho docente, dentre outras formas de abordar o tema.

Concordando com Tardif e Lessard (2005), consideramos o estudo da docência como um trabalho ainda negligenciado e dissociado de problemas situados no âmbito mais macro da questão. Os autores trazem à reflexão aspectos como a divisão e especialização do trabalho; a burocracia cada dia maior; o controle da administração local e de outras esferas externas (estaduais e federais); as condições materiais disponíveis; a carga horária; as relações com seus pares e com especialistas que atuam na escola; o quantitativo de alunos e os conteúdos e processos pedagógicos 


\section{ATOS DE

para desenvolvê-los. A ausência de todos esses pontos de análise, de acordo com os autores, são alguns dos contrapesos que deixam a discussão em desequilíbrio e empobrecida. Para além dos salários e das expectativas de carreira, são fatores que contribuem para um processo perverso de desvalorização do trabalho docente, cuja reflexão se faz urgente no âmbito das práticas cotidianas e das políticas que alinhavam essa discussão.

Levando em consideração esse contexto, Ludke e Boing (2012) elaboram argumentos para a reflexão, buscando suporte teórico em referencias de Labaree ${ }^{5}$, a partir da ideia de que "[...] o problema de fundo é o seguinte: ensinar é um trabalho enormemente difícil, que parece fácil" (LABAREE, 2004, apud LÜDKE E BOING, 2012, p. 431). Aliado ao disposto por Labaree sobre o difícil visto como fácil e, portanto, qualquer um pode executar, temos a socialização retroativa, na qual o professor iniciante ${ }^{6}$ toma como modelo as experiências vividas como aluno, situação em que sua condição como sujeito é diferente. Há, então, duas argumentações que pontuam o trabalho docente, mais uma vez, na seara de desvalorizações: (1) trabalho que parece fácil, somado a (2) professor que se autoforma, com suas experiências individuais e isoladas. Nesse jogo, há ainda outras desvalorizações que se referem à formação de professores e à profissão docente.

Mas, afinal, que trabalho realiza o professor? Onde se coloca o trabalho docente? Seguindo a lógica que utilizamos no início desta seção, reafirmamos a imprecisão na formulação a essa resposta. Duarte e Augusto (2007) realizaram uma análise das pesquisas produzidas por grupos consolidados na América Latina e que discutem o trabalho docente a partir das novas regulações da educação.

Um dos recortes da pesquisa, elaborado com material de Seminário da Rede de Estudos Sobre Trabalho Docente (REDESTRADO), trouxe à tona que esse trabalho é entendido como "[...] aquele que se refere ao processo de ensino/aprendizagem na regência de classe; englobando ainda as atividades realizadas com os demais trabalhadores da escola, pais e comunidade" (DUARTE; AUGUSTO, 2006, p. 8). A autonomia e as avaliações são citadas como variáveis que

\footnotetext{
${ }^{5}$ Sociólogo americano da Universidade de Stanford.

${ }^{6}$ Refere-se ao professor que se encontra no período inicial de exercício da docência ( 3 a 5 anos). É um período de transição de aluno a professor, no qual ele experimenta o exercício profissional em uma escola (MARCELO GARCÍA, 2010).
} 


\section{ATOS DE \\ PESQUISA \\ EM EDUCAÇÃO}

ISSN: 1809-0354

8

integram e contribuem para a análise do trabalho docente e as condições de trabalho. É importante destacar que o levantamento feito nesta investigação teve por amostra seis (6) produções acadêmicas de autores, recortes de investigação e de campo brasileiros, ainda que o evento tenha um caráter latino-americano.

As variáveis encontradas nessa pesquisa não são uma novidade, principalmente quando se trata das condições de trabalho dos professores da educação básica no Brasil, relacionadas diretamente à valorização desse trabalho. Devemos ressaltar que, entre essas condições, estão arroladas as condições materiais - como equipamentos, itens de consumo, material didático e carreira docente - salário, jornada de trabalho, contratos, 'tempos remunerados para 0 trabalho coletivo', formação continuada, ou seja, se refere às relações de trabalho. Nessa mesma perspectiva, situamos os estudos de Leher (2010), acrescentando como elementos intervenientes - o regime de trabalho, os concursos públicos e, reforçando, o tempo remunerado para estudos, o que nos leva a indagar: Qual o sentido do tempo, na valorização do trabalho docente?

A regulação da carreira docente, na Educação Básica, tem por caminhos de concretização a elaboração e implantação de planos de carreira, tema relevante e alvo de diversas pesquisas. A valorização dos professores está prevista na Constituição Federal de 1988, devendo contemplar esses planos de carreira e ingresso no magistério por concursos públicos. A Lei n. 9.424/1996, que regulamentou o Fundo de Manutenção e desenvolvimento do Ensino Fundamental e de Valorização do Magistério (Fundef), afirmou que pelo menos 60\% deste fundo seria aplicado na remuneração dos profissionais do magistério, determinando um prazo de seis (6) meses para elaboração e implantação de planos de carreira por estados, municípios e Distrito Federal. A Emenda Constitucional n. 53/2006 criou o Fundo de Manutenção e Desenvolvimento da Educação o Ensino Fundamental e de Valorização dos Profissionais da Educação (Fundeb), que recoloca o Plano de Carreira e Remuneração e vai além, ampliando-o para os demais profissionais da educação, não somente ao magistério, em planos únicos ou separados. Desde o PNE/2001 (Lei n. 10.172), o plano de carreira já deveria prever a jornada de tempo integral (preferencialmente em uma só escola), $20 \%$ a $30 \%$ da carga horária para 


\section{ATOS DE

planejamento e apoio à docência, piso salarial e promoção por mérito. Já no PNE/2014, a Meta 18 assegura:

(...) no prazo de 2 (dois) anos, a existência de planos de Carreira para os (as) profissionais da educação básica e superior pública de todos os sistemas de ensino e, para o plano de Carreira dos (as) profissionais da educação básica pública, tomar como referência o piso salarial nacional profissional, definido em lei federal, nos termos do inciso VIII do art. 206 da Constituição Federal.

Considerando o prazo estabelecido na Meta 18 para a implantação dos PCR, acompanhamos a plataforma do Observatório do $\mathrm{PNE}^{7}$, desde 2018. No que se refere à porcentagem de sistemas de ensino com o "plano de Carreira dos (as) profissionais da educação básica pública" definido, a informação que se mantém é a seguinte: "Não há indicador que permita o acompanhamento desta meta". Com base no indicador auxiliar "Porcentagem dos Munícipios com o plano de Carreira para o Magistério", a plataforma do Observatório apresenta, ainda em 2020, um dado de 2014, afirmando que "neste indicador, é possível acompanhar a porcentagem de cidades que possuem plano de carreira para os professores no Brasil nas regiões e unidades da federação. Em 2014, 89,6\% dos municípios brasileiros implantaram alguma medida nessa linha, enquanto $10,3 \%$ não o fizeram e $0,1 \%$ não responderam ao questionamento. A região com o melhor indicador é a Sul $(96,1 \%)$ e a região Norte possui o pior desempenho $(80,4 \%)$. Essas informações foram obtidas pelo Observatório, a partir dos dados da Pesquisa de Informações Básicas Municipais (Munic./2014), realizada pelo Instituto Brasileiro de Geografia e Estatística (IBGE).

Isso significa que são precários e pouco atualizados os dados que monitoram o cumprimento da Meta 18 pelo Observatório do PNE, o que justifica a empreitada que estamos enfrentando na realização desta pesquisa, ainda que nosso alcance seja apenas o estado do Rio de Janeiro.

Sintetizando, ao pensar sobre trabalho docente e valorização do magistério, nos perguntamos se as reflexões que apresentamos até este momento encontram guarida nos Planos Municipais de Educação, bem como nos Planos de Carreira e

\footnotetext{
7 O Observatório do PNE é uma plataforma de monitoramento do Plano Nacional de Educação (PNE), criada e mantida por iniciativa do Todos pela Educação - organização da sociedade civil que a lançou, junto a organizações ligadas à Educação e especializadas nas diferentes etapas e modalidades de ensino. Algumas das entidades que participaram da iniciativa, à época de sua criação, já não estão mais na parceria.
} 


\section{ATOS DE \\ PESQUISA \\ EM EDUCAÇÃO}

ISSN: 1809-0354

10

Remuneração dos municípios analisados. É essa resposta que buscamos, na seção a seguir.

\section{PME E PCR DE MUNICÍPIOS DO ESTADO DO RIO DE JANEIRO: PRESENÇA DA VALORIZAÇÃO DOCENTE E DA EDUCAÇÃO EM TEMPO INTEGRAL?}

Esta parte é dedicada à apresentação e análise dos Planos Municipais de Educação (PME) e Planos de Carreira e Remuneração (PCR) dos três municípios referenciados na introdução deste trabalho, visando à busca, nas bases legais, de quais aspectos foram considerados, ampliados, reelaborados ou abandonados para atingir a meta seis da educação em tempo integral. Nessa perspectiva, trabalhamos nas duas temáticas que constituem o estudo - tempo integral e valorização do magistério - levando em consideração o fato de que esses municípios possuem realidades diferenciadas, geográfica e socialmente falando, dentro do estado do Rio de Janeiro.

No que se relaciona à articulação entre educação em tempo integral e valorização do magistério, partimos do pressuposto de que para que se efetive a ampliação da jornada escolar, é preciso formação e valorização de profissionais do magistério adequadas a este fim; por isso, a busca nesses documentos legais, na expectativa de localizar essa correlação. Um plano, isoladamente, revela as intenções daquele grupo que o produziu. Porém, relacionar planos que dizem respeito a objetivos localizados na mesma área e que são interdependentes, como é o caso dos planos de educação e de carreira, parece ser um caminho para identificar ou aproximar os intentos das políticas públicas locais. Lancemos, então, nosso olhar a esses Planos, nos municípios que compõem esta etapa da pesquisa: Duque de Caxias, Miracema e Resende.

Duque de Caxias compõem o conjunto de 17 municípios que fazem parte da região Metropolitana do estado do Rio de Janeiro e caracteriza-se por sua atividade industrial, principalmente no ramo do petróleo. O Plano de Carreira e Remuneração do Magistério desse município (PCR-DC) foi aprovado em 1991 e, até o momento de nossa pesquisa, não havia outro documento mais atualizado. Após sua leitura e análise, inferimos que não responde aos anseios relacionados, tanto à educação em 


\section{ATOS DE \\ PESQUISA \\ EM EDUCAÇÃO}

ISSN: 1809-0354

11

tempo integral, quanto à valorização e formação do magistério que se expressam na legislação e nos debates educacionais contemporâneos.

Contudo, seu PME-DC é notadamente mais atual do que o PCR-DC. Instituído em 2015, possui uma estrutura diferente do PNE: a educação em tempo integral, por exemplo, não se constitui como uma meta específica, sendo citada no conteúdo de duas estratégias que visam expandir o número de matrículas em tempo integral nas creches e escolas de Ensino Fundamental. Sobre as questões que envolvem os profissionais do magistério nesse estudo, o documento aponta para a promoção de formação continuada dos docentes; piso salarial na faixa de cinco salários-mínimos; garantia de reposição salarial conforme índice de inflação e garantia de licenças para estudo aos servidores efetivos.

Miracema encontra-se no Noroeste do estado do Rio de Janeiro. Seu Plano de Carreira e Remuneração do Magistério (PCR-M) foi instituído em 2011 e como não foi produzido outro plano após a publicação do $\mathrm{PNE} / 2014$, temos indícios de que não houve preocupação em relação à promoção de adequações deste PCR à luz das metas do atual PNE. Não é surpresa, portanto, a ausência de referências à educação em tempo integral no respectivo documento. No que se refere à valorização dos profissionais do magistério da Educação Básica, suas diretrizes apontam, por exemplo, para a garantia de condições adequadas ao exercício da profissão, além da possibilidade de progressão e gratificação na carreira por tempo de serviço e titulação e, ainda, de licenças para capacitação e aperfeiçoamento.

Seu PME-M, instituído em 2015, no que tange à educação em tempo integral, reproduz integralmente o PNE/2014, tanto no caput da meta seis, quanto nas estratégias que a compõem. A temática também é citada em estratégias referentes ao ensino fundamental (meta 2) e no atendimento aos estudantes com deficiência (meta 4), com o intuito de implementar duas escolas em tempo integral voltadas especificamente a essas realidades. Cinco metas são destinadas à valorização e formação dos profissionais do magistério (Metas 14 a 18). Entre as estratégias que as compõem, destacamos as que se referem ao incentivo à participação em eventos científicos no município que possam promover uma aproximação da rede municipal com instituições de ensino superior; políticas para o fomento a bolsas de ingresso na pós-graduação e concessão de licenças remuneradas para os profissionais 


\section{ATOS DE \\ PESQUISA \\ EM EDUCAÇÃO}

ISSN: 1809-0354

12

matriculados nesses cursos; gratificações por nível de titulação e a equiparação salarial com os demais profissionais de nível superior.

Resende, município situado na região político administrativa do Médio Paraíba, é conhecido por seu parque industrial, bem como por seu principal atrativo turístico, o distrito de Visconde de Mauá. O Plano de Carreira e Remuneração do Magistério de Resende (PCR-R), implementado em 2014, não aborda questões relacionadas especificamente ao trabalho em escolas de tempo integral. Contudo, tem foco na formação e valorização dos profissionais da educação, indicando ações voltadas para "remuneração digna e condições adequadas", que incluem jornada de trabalho preferencialmente em tempo integral, em apenas uma instituição. Há também o incentivo à participação em cursos de formação continuada e progressão na carreira por tempo de serviço e nível de formação.

No Plano Municipal de Educação de Resende (PME-R), que foi implementado em 2015, encontramos referência à educação em tempo integral e à valorização e formação dos professores, respectivamente, nos pontos 3 e 12. A seção dedicada à educação em tempo integral reproduz a meta estabelecida no PNE ressaltando, entre suas estratégias, o caráter facultativo da adesão ao período de tempo integral nas instituições escolares, que só deve ser feita em diálogo com o projeto político pedagógico da escola e após análise das condições efetivas que a instituição de ensino possui para a ampliação do período diário de escolarização. Também há previsão de construção ou adequação dos prédios escolares para atividades pedagógicas em tempo integral e incentivo à formação continuada específica aos docentes atuantes nas instituições que ofertam educação integral.

O ponto 12, referente à formação e valorização do magistério estabelece, como meta, a garantia à "formação, a jornada e condição de trabalho, a carreira, a remuneração, a saúde, a segurança e a aposentadoria, a fim de valorizar" os respectivos profissionais. As estratégias se orientam pelo cumprimento da lei do piso salarial dos professores; da garantia de $1 / 3$ da carga-horária dos professores para planejamento e organização e avaliação das atividades; regime de trabalho em apenas uma instituição; incentivo à formação continuada em nível de pós-graduação lato e stricto sensu; participação e publicação de trabalhos científicos em eventos da área e revisão do plano de cargos, a cada três anos. 


\section{ATOS DE \\ PESQUISA \\ EM EDUCAÇÃO}

ISSN: 1809-0354

13

Sintetizados os principais documentos legais com que trabalhamos nesta seção, em uma análise preliminar, podemos dizer que nos PCR dos três municípios selecionados há uma ausência significativa em relação ao trabalho do magistério em escolas que funcionem em tempo integral. Excetuando o município de Resende, em que encontramos a proposição de "jornada de trabalho preferencialmente em tempo integral e em apenas uma instituição", nenhum outro PCR se mostrou sensível a uma reflexão que contemplasse - e valorizasse - a ampliação do tempo escolar na rotina pedagógica do magistério, dentro de um mesmo espaço escolar.

Ainda em relação a esses PCR, constatamos uma generalização acentuada, no que tange à valorização dos docentes. Nos três municípios, encontramos proposições que encerram incentivos à formação em nível de pós-graduação, como licenças remuneradas e progressão. Novamente, o município de Resende se destaca ao indicar a necessidade de formação específica para professores que atuam em escolas de tempo integral. Também verificamos um 'empenho discursivo', no sentido de propiciar "condições adequadas ao exercício da profissão" e "progressão e gratificação na carreira por tempo de serviço e titulação". No entanto, essas postulações não são acompanhadas dos meios e recursos necessários ao atingimento de tais finalidades. Ressaltamos, novamente, a desatualização do PCRDC, não possibilitando uma análise mais eficiente desse município em relação a esse documento legal.

Quanto aos PME, os documentos de Miracema e Resende discorrem a respeito da educação em tempo integral com meta e estratégias para seu cumprimento. Mais uma vez, Duque de Caxias é evidenciado por não apresentar meta específica nesse sentido, embora, em outros momentos de seu Plano, a expansão do número de matrículas em tempo integral nas creches e escolas de Ensino Fundamental é citada como possibilidade. Miracema prevê a construção de duas escolas de tempo integral, mas não apresenta a fonte dos recursos a serem utilizadas nestas construções.

No que se refere à formação do magistério, a maioria dos Planos possui estratégias que propõem licenças remuneradas, bolsas de estudo e incentivos para que ela se efetive. Em Resende, inclusive, a proposta é que haja formação específica para os profissionais que atuam com o tempo integral, como já evidenciamos anteriormente. Quanto à valorização dos professores, em termos de remuneração, 


\section{ATOS DE \\ PESQUISA \\ EM EDUCAÇÃO}

ISSN: 1809-0354

14

propõe-se desde piso salarial na faixa de cinco salários mínimos (PME-DC) até o cumprimento do piso salarial dos professores e a equiparação desse piso ao dos demais profissionais de nível superior (PME-R).

Em resumo, essa análise mais geral nos levou à constatação de que o tempo integral, enquanto Meta a ser perseguida pelas políticas públicas - na devida proporção de sua articulação com a formação e a valorização do magistério -, caminha de forma descompassada, tanto nos Planos Municipais de Educação, quanto nos Planos de Carreira e Remuneração do Magistério nos municípios de Duque de Caxias, Miracema e Resende, nosso recorte neste artigo. Nesse contexto, nossas reflexões nos encaminharam à busca de uma resposta para a questão que dá título à próxima seção.

\section{EM PROPOSTAS MUNICIPAIS DE EDUCAÇÃO EM TEMPO INTEGRAL NO ESTADO DO RIO DE JANEIRO, VALORIZA-SE O TRABALHO DOCENTE?}

Após análise dos PCR e PME de Duque de Caxias, Miracema e Resende, perguntamo-nos a respeito do 'futuro' das políticas de ampliação da jornada escolar para o tempo integral existentes nesses municípios. Consideramos que os sujeitos em ação - professores - não estão contemplados no ordenamento legal que as embasa, com estratégias que lhes garantam um mínimo de condições materiais, de formação e de valorização de carreira para abraçarem a tarefa de educar, sistemática e intencionalmente, os milhares de estudantes do Ensino Fundamental, em escolas em que a natureza da ampliação de jornada se faça presente e atuante.

Os resultados obtidos a partir das análises de tais documentos apontam também que, no contexto dos municípios em questão, a formação e a valorização do magistério possuem maior escopo do que os referentes à educação em tempo integral. Levantamos como possível hipótese para tal cenário o fato dessa formação e valorização ser uma possibilidade que acompanha os debates educacionais em nível nacional há décadas, enquanto a educação em tempo integral se configura como um tema que emerge e perde força, a depender da conjuntura política e social que permeia nossas políticas educacionais - sejam elas federais, estaduais ou municipais. 


\section{ATOS DE \\ PESQUISA \\ EM EDUCAÇÃO}

ISSN: 1809-0354

Nas duas últimas décadas, contemporaneamente, vimos nos deparando com cenário favorável à centralidade e problematização dos debates acerca da educação em tempo integral, especialmente quando, pela primeira vez, a ela foi atribuída a condição de meta específica do PNE. Entendemos que esses fatos não são os únicos, mas certamente contribuem para a compreensão do porquê a formação e valorização possuem centralidade, tanto nos planos de carreira docente, quanto nos planos municipais de educação, enquanto a educação em tempo integral configura-se como um tema emergente nos PME analisados, sem receber, contudo, a mesma atenção nos PCR. Não obstante, tal fato nos auxilia, igualmente, a compreender a falta de articulação entre formação e valorização, quando aproximamos tais aspectos à educação em tempo integral.

Outra questão que nos chama atenção, refere-se à pouca articulação entre Educação em Tempo Integral e Formação de Professores. O município de Resende, dos três analisados, foi o único a estabelecer tal relação e, mesmo assim, sem detalhar como e em quais bases essa formação se daria.

A leitura atenta dos ordenamentos legais apresentados evidenciou, também, a presença de algumas parcerias público-privadas. Os municípios de Miracema e de Resende são explícitos, ao declararem a possibilidade dessas presenças, tanto em estratégias relacionadas à implantação do tempo integral, quanto no que tange à formação do magistério. Resende, inclusive, cita um parceiro, o Instituto de Educação do Município de Resende (EDUCAR), já no início de seus documentos legais. O EDUCAR, segundo informações do site oficial da Prefeitura, é um organismo governamental criado com a finalidade de executar a Política Municipal da Educação e tem o objetivo de "[...] prover, promover e fomentar, com a colaboração da sociedade, a Educação como direito fundamental da cidadania, em coordenação com as demais entidades do Município, Estado e União, e na conformidade das diretrizes estabelecidas pela legislação vigente" (RESENDE-MUNICÍPIO, 2018, p.1). A menção à 'colaboração da sociedade' nos dá condições de inferir sobre a possibilidade de parcerias público privadas, o que não foi possível avaliar com mais detalhamento. No mesmo site oficial, está disponível o Ambiente Virtual de Aprendizagem para a Educação (AVA - EDUCAR), que é um ambiente Moodle, com cursos na modalidade 


\section{ATOS DE

a distância disponibilizados aos professores da rede de escolas públicas de Resende 8 . Há indícios de se tratar de uma estratégia de realização de formação continuada de professores por meio do EDUCAR, o que não nos cabe avaliar no presente trabalho, por fugir ao seu escopo. No entanto, fica a interrogação: em se realizando formações continuadas, nessa parceria, haverá alguma discussão que articule o trabalho docente em escolas em tempo integral?

Em síntese, após apresentação e discussão dos PME e PCR dos municípios fluminenses de Duque de Caxias, Miracema e Resende identificamos, na análise realizada, os aportes teóricos discutidos constatando-se, por exemplo, que tempo efetivo de planejamento e atuação em uma única escola são aspectos inscritos nas dimensões objetivas da valorização docente, mas que, não necessariamente, encontram eco nos Planos Municipais de Educação que evidenciamos. Essa questão é tangenciada no PME do município de Resende, apenas.

Também é possível afirmar que, pelo menos em âmbito legal, a valorização do magistério está posta, nela incluindo o 'tempo' para formação docente, não necessariamente afeito às questões da ampliação da jornada escolar, mas sua presença já indica um norte na direção de uma formação mais qualificada para esses sujeitos em atuação nas escolas públicas desses municípios.

Por outro lado, a ausência de maior detalhamento em relação à articulação entre projetos de educação em tempo integral e formação-valorização do magistério impõe a pergunta que nos fizemos, quando da elaboração deste estudo: estarão as estratégias que valorizam o trabalho docente afinadas com qual concepção de ampliação da jornada escolar: a que evidencia a natureza de uma escola de tempo integral, ou a que privilegia o aluno em tempo integral (CAVALIÉRE, 2009)?

Nesse caminho, retomamos significativo estudo da temática, desenvolvido por Cavaliére (2009) quando trabalhou duas possibilidades de compreensão do 'tempo integral'. Segundo a autora, por um lado, o pressuposto de que a ampliação da jornada escolar não pode prescindir de uma formação integral, multidimensional e integrada, com atividades articuladas ao projeto político das escolas, é denominado como escola

\footnotetext{
${ }^{8}$ No momento da pesquisa, eram estes os cursos: Curso de Formação de Gestores Escolares da REMEP (Rede Municipal de Escolas Públicas) e Tecnologia em sala de aula, além do Curso Básico AVA-EDUCAR, destinado às orientações no uso da plataforma. Havia também um espaço destinado às orientações para o uso do Diário Eletrônico.
} 


\section{ATOS DE \\ PESQUISA \\ EM EDUCAÇÃO}

ISSN: 1809-0354

17

de tempo integral. Em outras palavras, é uma proposição que se baseia na natureza primeira da instituição escolar, levando em consideração que todas as crianças e jovens que a ela acorrem são sujeitos potenciais de apropriação de conhecimentos, saberes, habilidades, enfim, de múltiplos aspectos que compõem a formação humana.

Por outro lado, em perspectiva diversa, a escola resume sua função a assistir os estudantes, como forma de tirá-los da condição de vulnerabilidade em que se encontram, muitas vezes apoiando as atividades desenvolvidas na escola em equipamentos culturais existentes em outros espaços, para além do escolar. Segundo Cavaliére (2009), tal abordagem preconiza o aluno em tempo integral, ou seja, a escola se fraciona em grupos de estudantes: os que - por alguma condição de vulnerabilidade - terão sua jornada escolar ampliada para o tempo integral, com atividades no contraturno e que podem acontecer nesse espaço formal de ensino, em equipamento cultural outro ou, ainda, em espaços da cidade e aqueles que - não se situando nesse critério, não participarão dessas mesmas atividades. Porém, que relação essa reflexão apresenta com o estudo e as questões que aqui elaboramos?

Ao problematizamos as metas e estratégias contempladas nos PME e PCR dos municípios fluminenses de Miracema, Resende e Duque de Caxias, visando à implantação de uma educação escolar em tempo integral, encontramos indícios de que a proposta denominada aluno em tempo integral encontra-se mais presente do que a de escola de tempo integral. Em outros termos - e focando em nosso objeto de estudo - as possibilidades que são apresentadas para a formação e valorização do magistério nesses municípios, quando articuladas à ampliação do tempo escolar, evidenciam muito mais uma postura em que o cerne deixa de ser a escola funcionando em tempo integral, buscando uma perspectiva emancipatória e crítica. Vejamos mais profundamente como a situação se apresenta.

À primeira vista, a opção feita pelos municípios fluminenses que pesquisamos parece coerente: Alguém diria que trabalhar em outros espaços educativos que não os da educação formal, bem como privilegiar alunos em situação de vulnerabilidade são atitudes questionáveis? Parece-nos óbvio que a resposta a essa pergunta é negativa.

Contudo, quando a ampliação da jornada não é pensada tendo como norte o espaço escolar a que os estudantes acorrem, ou ainda, quando se parte do 


\section{ATOS DE \\ PESQUISA \\ EM EDUCAÇÃO}

ISSN: 1809-0354

18

pressuposto de que, em uma mesma unidade escolar, alguns alunos são mais vulneráveis do que outros e, nesse sentido, as atividades que desempenham serão diferenciadas, muito frequentemente a proposta apresentada fundamenta-se em outros pressupostos. E esses não encerram a constituição de uma formação mais multidimensional e integrada de formação humana crítica e emancipadora.

Se o projeto de ampliação de jornada escolar se norteia pela formação multidimensional mais integral e humana, ao pensar no sujeito aluno, não deve - e nem pode - descuidar de (i) pensar que todos os alunos são sujeitos dessa formação; (ii) evidenciar espaços intra e extraescolares capazes de também ampliar a formação desse estudante; (iii) possibilitar um tempo mais qualitativo durante a presença do aluno na escola, com atividades mais coletivas e participativas que podem se mesclar a outras, de forma integrada e articulada e, mais especificamente em relação ao objeto de nosso estudo; (iv) focar sua ação no professor procurando, por meio da elaboração de PCR, que suas atividades possam se desenvolver em um ambiente mais dialógico, participativo, em que o trabalho entre pares seja privilegiado e onde sua atividade pedagógica seja evidenciada em tempo integral.

Conforme foi possível descrever na seção anterior, tanto os PME quanto os PCR de Miracema, Resende e Duque de Caixas apresentam, em sua maioria, estratégias que envolvem o tempo integral nas escolas. Porém, em poucas oportunidades essas mesmas estratégias entram em consonância com o papel/função de um professor que, trabalhando igualmente em tempo integral na mesma instituição escolar, possa desenvolver um trabalho que leve em conta a formação multidimensional do estudante com que atua.

Em outros termos, o que se projeta é a evidência de propostas em que alguns 'alunos' estão em tempo integral nas escolas, mas provavelmente sem um trabalho docente que Ihes proporcione uma apropriação mais autônoma, crítica e criativa dos conhecimentos e saberes que a instituição Ihes deve apresentar: a ausência de estratégias que levem em conta a formação e valorização do magistério - nos PME e PCR analisados - reforça essa tendência.

Em resumo, ao se pensar em uma proposta de educação escolar em tempo integral em que a educação integral na perspectiva da formação multidimensional e crítico-emancipadora se faça presente, é essencial pensar também na formação dos 


\section{ATOS DE \\ PESQUISA \\ EM EDUCAÇÃO}

ISSN: 1809-0354

19

professores para atuarem nessa realidade, cuja ampliação da jornada the faculta momentos mais significativos de interação, integração e de apropriação de saberes. É igualmente importante que esse docente veja valorizado o seu trabalho, com uma carga horária adequada na escola, possibilitando planejamentos coletivos, trocas entre pares e com os estudantes, além de uma remuneração condizente com a responsabilidade que assume para com esses mesmos estudantes.

\section{CONSIDERAÇÕES FINAIS}

Sumarizando este estudo, buscamos contribuir para com o debate acerca dos desafios encontrados quando a discussão se encaminha à valorização do trabalho docente, mais especificamente, quando o foco desta discussão são as propostas/políticas de ampliação da jornada escolar para o tempo integral. Nessa empreitada, partimos de recorte realizado em uma pesquisa mais ampla, analisando o ordenamento legal - PME e PCR - de três dos municípios que compõem o estado do Rio de Janeiro: Duque de Caxias, Miracema e Resende.

Nossos resultados parciais apontaram que a articulação entre formação e valorização do magistério, associada a projetos de educação em tempo integral e, especialmente à concepção de ampliação da jornada escolar com uma proposta de educação integral crítica, nesses três municípios, não se faz presente, efetivamente. O que temos são indícios, pistas que não se materializam em concretude tal, capaz de estabelecer vínculos fortes (e necessários) à emancipação de estudantes, e também dos sujeitos que com eles atuam, no tempo integral.

Especificando mais, para ambas as categorias de análise, os documentos são genéricos e as propostas não se materializam em estratégias que evidenciem financiamento alocado para as metas relativas ao tempo integral e à formação e valorização do magistério. Não se identifica uma correlação efetiva entre a formação e valorização com as contrapartidas nos PCR. Valorizar o professor não pode ser tão somente um discurso oficial e legal, aprovado e publicado em Diários Oficiais de cada um dos municípios, que não expressem um valor atribuído ao trabalho docente, garantindo melhoria das condições físicas e humanas, bem como a qualidade desse trabalho e remuneração compatível com a sua realização. 


\section{ATOS DE \\ PESQUISA \\ EM EDUCAÇÃO}

ISSN: 1809-0354

20

Nessa perspectiva, não se deve esquecer que os $\mathrm{PCR}$, para servirem como materialização de um processo de valorização do magistério, também precisam apresentar uma carreira que seja não somente desafiadora, mas também atrativa, do ponto de vista de salário e de status social. Estes fatos não foram identificados neste estudo.

Planejada para ser realizada em um percurso de quatro anos, a pesquisa interinstitucional que ensejou o estudo encontra-se em seu segundo ano de investigações. Outros municípios que compõem o estado do Rio de Janeiro estão sendo investigados; os estudos e reflexões que temos estabelecido com os documentos legais dessas cidades e com representantes das Secretarias Municipais a que pertencem tem evidenciado situação semelhante a que encontramos em Duque de Caxias, Miracema e Resende, com raras exceções. Essa situação nos leva a inferir que a formação e valorização do magistério é problema cujas soluções dependem da vontade política daqueles que se encontram no poder, mas também dos sujeitos que atuam, profissionalmente, nesse contexto - os docentes.

Nesse sentido, cabe a nós - sujeitos em atuação - o movimento reivindicatório, assim como a busca por espaços mais dialógicos de trabalho em que, coletivamente, possamos discutir questões pedagógicas e políticas que nos afetam, no cotidiano escolar. Com mais tempo de planejamento e estudo nesse espaço formal de ensino, esses momentos poderão se tornar mais frequentes e compromissados com uma educação emancipadora.

\section{LÍGIA MARTHA C. C. COELHO}

Doutora em Educação (UFRJ); Docente do Programa de Pós-Graduação em Educação da Universidade Federal do Estado do Rio de Janeiro (PPGEdu/UNIRIO). Coordenadora do Núcleo de Estudos - Tempos, Espaços e Educação Integral (NEEPHI/UNIRIO/CNPQ).

\section{DAYSE MARTINS HORA}

Doutora em Educação (PUC-SP). Docente do Programa de Pós-Graduação em Educação da Universidade Católica de Petrópolis (UCP). Pesquisadora vinculada ao Núcleo de Estudos - Tempos, Espaços e Educação Integral (NEEPHI/UNIRIO/CNPQ).

\section{RAPHAEL MOTA GUILARDUCCI}

Doutorando em Educação (UFRJ); Mestre em Educação (UNIRIO); Graduado em Educação Física (UFLA). Pesquisador vinculado ao Núcleo de Estudos - Tempos, Espaços e Educação Integral (NEEPHI/UNIRIO/CNPQ). Bolsista PROEX-CAPES. 


\section{ATOS DE
PESQUISA
EM EDUCAÇÃO}

ISSN: 1809-0354

\section{REFERÊNCIAS}

ANTUNES, R. O caracol e sua concha. Ensaios sobre a nova morfologia do trabalho. São Paulo: Boitempo. 2005.

BRASIL. Constituição da República Federativa do Brasil. Brasília, DF: Senado Federal, 1988. Disponível em:

http://www.planalto.gov.br/ccivil_03/constituicao/constituicaocompilado.htm. Acesso em: 28 set. 2018.

BRASIL. Lei no 9.394, de 20 de dezembro de 1996. Estabelece as diretrizes e bases da educação nacional. Disponível em:

http://www.planalto.gov.br/ccivil_03/LEIS/L9394.htm. Acesso em: 28 set. 2018.

BRASIL. Lei n. 9.424/1996, de 24 de dezembro de 1996. Dispõe sobre o Fundo de Manutenção e Desenvolvimento do Ensino Fundamental e de Valorização do Magistério, na forma prevista no art. 60, § $7^{\circ}$, do Ato das Disposições Constitucionais Transitórias, e dá outras providências. Diário Oficial da República Federativa do Brasil. Brasília, 26 dez. 1996.

BRASIL. Lei no 10.172, de 9 de janeiro de 2001. Aprova o Plano Nacional de Educação e dá outras providências. Diário Oficial da República Federativa do Brasil. Brasília, 10 jan. 2001.

BRASIL. Emenda Constitucional n. 53, de 19 de dezembro de 2006. Dá nova redação aos arts. $7^{\circ}, 23,30,206,208,211$ e 212 da Constituição Federal e ao art. 60 do Ato das Disposições Constitucionais. Diário Oficial da República Federativa do Brasil. Brasília, 20 dez. 2006.

BRASIL. Ministério da Educação. Conselho Nacional de Educação. Resolução CNE ํo 2, de 28 de maio de 2009. Fixa Diretrizes Nacionais para os Planos de Carreira e Remuneração dos Profissionais do Magistério da Educação Básica Pública (...). Diário Oficial da República Federativa do Brasil. Brasília, 29 maio. 2009.

BRASIL. Lei no 13.005, de 25 de junho de 2014. Aprova o Plano Nacional de Educação - PNE e dá outras providências. Diário Oficial da República Federativa do Brasil, Seção 1 - Edição Extra, p.1. Brasília, 26 jun. 2014.

BRASIL. Ministério da Educação. Secretaria de Articulação com os Sistemas de Ensino. Planos de carreira e remuneração: contribuições para a elaboração e a revisão de planos de carreira e remuneração dos profissionais da educação escolar básica pública. Brasília: MEC/SASE. 2016.

CAVALIÉRE, A. M. Escolas de tempo integral versus alunos em tempo integral. Em Aberto, v. 22, n. 80, p. 51-63, abr. 2009. Disponível em: 


\section{ATOS DE \\ PESQUISA \\ EM EDUCAÇÃO}

ISSN: 1809-0354

22

http://emaberto.inep.gov.br/index.php/emaberto/article/download/2220/2187. Acesso em: 10 jan. 2019.

DUARTE, A., AUGUSTO, M. H. Trabalho docente: configurações atuais e concepções. In: XXIII Simpósio Brasileiro de Política e Administração da Educação, Porto Alegre. 2007. Disponível em:

http://www.anpae.org.br/congressos_antigos/simposio2007/03.pdf. Acesso em: 13 out. 2018.

DUQUE DE CAXIAS (Município). Lei no 1.070, de 19 de setembro de 1991. Institui o Plano de Carreira dos Profissionais da Educação do Município, e dá outras providências. Boletim Oficial do Município de Duque de Caxias. Duque de Caxias (RJ), 1991.

DUQUE DE CAXIAS (Município). Lei no 2.713, de 30 de junho de 2015. Aprova a adequação do Plano Municipal de Educação ao Plano Nacional de Educação para o Decênio 2015/2025 e dá outras providências. Boletim Oficial do Município de Duque de Caxias. Duque de Caxias (RJ), 2015.

FIGARO, R. O mundo do trabalho e as organizações: abordagens discursivas de diferentes significados. Organicom, v. 5, n. 9, p. 90-100. Jul/dez. 2008. Disponível em: http://www.revistas.usp.br/organicom/article/view/138986. Acesso em: 10 jan. 2019.

LEHER. R. Valorização do magistério. In Oliveira, D., Duarte, A., Vieira, L. DICIONÁRIO: trabalho, profissão e condição docente. Belo Horizonte: UFMG. 2010.

LIMA, M., WEBER, D., MARTINI, R. Trabalho docente: um trabalho alienado? Revista Faced, n. 13, p. 13-31, jan/jun. 2008. Disponível em: https://portalseer.ufba.br/index.php/entreideias/article/view/3204. Acesso em: 10 jan. 2019.

LÜDKE, M.; BOING, L. A. Do trabalho à formação de professores. Cadernos de Pesquisa, v. 42, n.146, p. 428-451, maio/ago. 2012. Disponível em: http://www.scielo.br/pdf/cp/v42n146/07.pdf. Acesso em: 10 jan. 2019.

MARCELO GARCÍA, C. Políticas de inserción a la docencia: de eslabón perdido a puente para el desarrollo profesional docente. 2010. Disponível em:

http://www.ub.edu/obipd/docs/politicas_de_insercion_a_la_docencia_del_eslabon_p erdido_al_puente_para_el_desarrollo_profesional_docente_garcia_c_m.pdf. Acesso em: 25 abr. 2020.

MIRACEMA (Município). Lei no 1.602, de 18 de junho de 2015. Aprova o plano municipal de educação para o decênio 2015-2025, e dá outras providências. Boletim Oficial do Município de Miracema. Miracema (RJ), 30 jun. 2015.

MIRACEMA (Município). Lei oㅜ 1.367, de 08 de setembro de 2011. Revoga a Lei 699/98 de 04 de maio de 1988, disciplina a Instituição do Plano de Carreira e 


\section{ATOS DE
PESQULSA
EM EDUCACCAO}

ISSN: 1809-0354

23

Remuneração do Magistério Público de Miracema. Boletim Oficial do Município de Miracema. Miracema (RJ), 15 set. 2011.

MOVIMENTO TODOS PELA EDUCAÇÃO (Coordenador). Observatório do Plano Nacional de Educação. 2013. Disponível em: http://www.observatoriodopne.org.br/. Acesso em: 21 out. 2018.

RESENDE (Município). Lei oㅜ 3.074, de 21 de janeiro de 2014. Dispõe sobre o novo estatuto do magistério e dos demais profissionais da educação do município de Resende, e dá outras providências. Boletim Oficial do Município de Resende. Resende (RJ), 24 jan. 2014.

RESENDE (Município). Lei no 3.075, de 21 de janeiro de 2014. Dispõe sobre o novo plano de carreira e remuneração do magistério e dos demais profissionais da educação pública municipal (PCR), e dá outras providências. Boletim Oficial do Município de Resende. Resende (RJ), 24 jan. 2014.

RESENDE (Município). Lei no 3.190, de 01 de julho de 2015. Aprova o plano municipal de educação do município de Resende para o decênio 2015-2025. Boletim Oficial do Município de Resende. Resende (RJ), 03 jul. 2015.

RESENDE (Município). Secretaria Municipal de Educação, EDUCAR - Instituto da Educação do Município de Resende. Portal da Educação. Resende, 2018. Disponível em: http://educacao.resende.rj.gov.br/sme-educar/. Acesso em: 03 nov.2018.

TARDIF, M. E LESSARD, C. O trabalho docente: elementos para uma teoria da docência como profissão de interações humanas. Petrópolis, RJ: Vozes. 2005.

Recebido em: 26/07/2020.

Aprovado em: 22/09/2020. 